\title{
Penyakit Respiratorik pada Anak dengan HIV
}

\author{
Finny Fitry Yani*, Arwin AP Akib**, Bambang Supriyatno*, Darmawan B. Setyanto*, Nia Kurniati*, \\ Nastiti Kaswandani**
}

Latar belakang. Kejadian AIDS pada anak meningkat seiring dengan peningkatan kasus dewasa. Gejala dan manifestasi klinis sering tidak khas, sehingga menyebabkan underdiagnosis. Anak HIV sering datang dengan keluhan yang berasal dari infeksi oportunistik, bahkan infeksi oportunistik banyak ditemukan sebagai penyebab kematian. Salah satu infeksi oportunistik yang sering terjadi adalah infeksi respiratorik.

Tujuan penelitian. Penelitian ini bertujuan untuk melihat pola penyakit respiratorik pada anak HIV yang dirawat di Bagian Ilmu Kesehatan RS Dr. Cipto Mangunkusumo (RSCM), Jakarta.

Metoda. Data berasal dari rekam medis anak HIV tahun 2002-2005. Penelitian dilakukan dengan desain potong lintang. Kriteria inklusi adalah anak usia 0-13 tahun, dengan HIV positif dan menderita penyakit respiratorik. Data yang dicatat meliputi umur, jenis kelamin, faktor risiko, status gizi, parut BCG, diameter uji tuberkulin, riwayat kontak dengan pasien tuberkolosis, kategori HIV, diagnosis penyakit respiratorik, outcome. Data klinis khusus meliputi batuk kronik berulang, demam lama, sesak nafas, laboratorium rutin, foto torak, dan kadar CD4, PCR.

Hasil. Sejak Januari 2002-Desember 2005, telah dirawat 85 anak yang terinfeksi HIV, dengan 13 orang $(15,2 \%)$ di antaranya meninggal. Tiga belas orang (13/35) didiagnosis HIV berdasarkan serologi dan PCR, 24/35 hanya dengan serologi, dan 1/35 orang dengan PCR. Sebanyak $38(44,7 \%)$ orang menderita infeksi respiratorik dengan pola penyakit: TB $47,3 \%$, pneumonia 44,7\%, pneumocytis corinii pneumonia (PCP) $13,1 \%$. Pada penelitian ini, didapatkan bahwa $3 / 38(7,8 \%)$ anak HIV dengan penyakit paru meninggal karena pneumonia berat, dengan $2 / 3$ di antaranya pada kelompok umur 1-5 tahun. Penyebab kematian lainnya adalah PCP $2 / 38$ pasien $(5,2 \%)$, dan tersangka sepsis pada 2 pasien $(5,2 \%)$. Kesimpulan. Pada anak HIV, TB merupakan penyakit respiratorik terbanyak, diikuti pneumonia, sedangkan penyebab kematian terbanyak adalah pneumonia. Penyakit respiratorik pada anak HIV dapat menjadi pembuka jalan untuk diagnosis anak HIV.

Kata kunci: HIV, penyakit respiratorik

\footnotetext{
Alamat korespondensi:

Dr. Arwin AP Akib, Sp.A(K) **. Divisi Alergi Imunologi. Departemen Ilmu Kesehatan Anak FKUI RSCM, Jakarta. Jl. Salemba No. 6, Jakarta 10430. Telepon 021-316 1144. Fax. 0213907743.

Dr. Darmawan B Setyanto Sp.A(K)* Divisi Respirologi Departemen Ilmu Kesehatan Anak FKUI-RSCM Jl. Salemba no. 6, Jakarta 10430. Telepon: 021-3100669. Fax.021-390 7743

Dr. Finny Fitry Yani, SpA* Divisi Respirologi Departemen IKA FK Universitas Andalas Padang
}

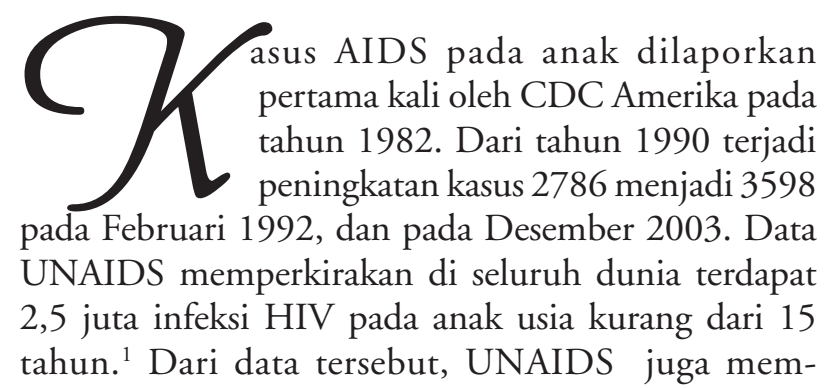


perkirakan bahwa pada tahun 2010 akan terjadi peningkatan kematian anak HIV di daerah prevalensi infeksi infeksi HIV tinggi, seperti sub Sahara Afrika. ${ }^{2}$

Dengan meningkatnya kasus HIV/AIDS dewasa di Indonesia, maka anak Indonesia juga memiliki risiko tinggi untuk terinfeksi. Akan tetapi, sampai saat ini kasus yang teridentifikasi secara pasti belum banyak, sehingga besaran masalahnya belum dapat ditentukan.

Beberapa keadaan yang menimbulkan kecurigaan terhadap infeksi HIV pada anak adalah adanya infeksi rekuren atau infeksi biasa yang tidak sembuh dengan pengobatan biasa, dan dapat disertai dengan malnutrisi serta gagal tumbuh. Bahkan, seringkali tanda dan gejala infeksi oportunistik merupakan presentasi pertama dari gejala klinis HIV. ${ }^{1}$ AIDS Related Illnes (ARI) juga dapat dipakai sebagai indikator untuk memulai terapi dengan Anti Retro Viral. ${ }^{3}$

Penyakit respiratorik merupakan penyebab terbesar kesakitan dan kematian pada HIV. ${ }^{4}$ Infeksi respiratorik merupakan salah satu infeksi oportunistik yang sering menyerang anak dengan HIV, seringkali berupa pneumonia ataupun tuberkulosis. Sebuah penelitian di Zimbabwe menemukan pada anak seropositif HIV terdapat infeksi pneumonia 32\% dan tuberkulosis 5\%.5 Pneumonia sering menjadi penyebab kematian pada populasi ini, yaitu 32,3\% pada anak usia $<6$ tahun. ${ }^{6}$ Sampai saat ini di Indonesia belum ada data klinis keterlibatan repiratorik pada anak dengan HIV.

Penelitian ini bertujuan untuk melihat pola penyakit respiratorik pada anak HIV di Departemen Ilmu Kesehatan Anak RSUP Cipto Mangunkusumo Jakarta.

\section{Metoda}

Sampel berasal dari data sekunder rekam medik pasien rawat inap dan rawat jalan di Departemen Ilmu Kesehatan Anak RSUP Cipto Mangunkusumo, sejak Januari 2002 - Desember 2005. Penelitian dilakukan dengan desain potong lintang retrospektif.

Pasien yang diikutsertakan ke dalam penelitian adalah anak yang berumur 0-13 tahun, HIV positif dan menderita penyakit respiratorik. Data yang dicatat meliputi umur, jenis kelamin, faktor risiko, status gizi, parut BCG, diameter uji tuberkulin, kontak TB, kategori HIV, diagnosis penyakit respiratorik, outcome. Data klinis khusus meliputi batuk kronik berulang, demam lama, sesak nafas, laboratorium rutin, foto torak, dan kadar CD4, PCR.

\section{Definisi operasional}

Anak didiagnosis HIV berdasarkan hasil uji serologi reaktif terhadap HIV dan atau pemeriksaan kadar PCR dan atau terdapat penyakit yang dihubungkan dengan HIV (AIDS Related Illness = ARI). Diagnosis penyakit respiratorik berdasarkan klinis, laboratorium dan foto torak. Kategori HIV dan status imunitas disesuaikan dengan klasifikasi CDC revisi 1994.

\section{Hasil Penelitian}

Sejak Januari 2002-Desember 2005, telah didiagnosis 85 anak yang terinfeksi HIV, dengan 13 orang $(15,2 \%)$ di antaranya meninggal. Sebanyak $38(44,7 \%)$ orang menderita infeksi respiratorik dengan pola penyakit tertera pada Tabel 1. Jumlah laki-laki sama dengan perempuan yaitu masing-masing $50 \%$, dengan ratarata usia 24,1 bulan. Tujuh orang di antaranya ( $18,4 \%)$ meninggal, dengan rata-rata usia kematian 15,8 bulan . Tiga belas orang (13/35) didiagnosis HIV berdasarkan serologi dan PCR, 24/35 hanya dengan serologi, dan $1 / 35$ orang hanya dengan PCR.

Tabel 1. Hasil pemeriksaan PCR HIV pada 14 kasus di antara 38 pasien dengan penyakit respiratorik

\begin{tabular}{lcrl}
\hline No & No Kasus & $\begin{array}{r}\text { Kadar PCR } \\
\text { (copy DNA) }\end{array}$ & \multicolumn{1}{c}{$\begin{array}{c}\text { Diagnosis penyakit } \\
\text { respiratorik }\end{array}$} \\
\hline 1. & 1 & 3.034 .420 & TB \\
2. & 3 & 600.000 & BKB \\
3. & 5 & 367.053 & TB \\
4. & 11 & 642.414 & Pneumonia, TB \\
5. & 12 & 1.109 .380 & Pneumonia, TB \\
6. & 13 & 474.258 & Pneumonia \\
7. & 14 & 750.000 & Pneumonia, TB \\
8. & 15 & 435 & TB \\
9. & 16 & 562.362 & Pneumonia \\
10. & 19 & 750.000 & Pneumonia \\
11. & 21 & 1.949 .133 & BCGitis \\
12. & 22 & 1.168 .301 & TB \\
13. & 35 & 462 & Pneumonia \\
14. & 38 & 1216.268 & Pneumonia, TB \\
\hline
\end{tabular}

Catatan: $\mathrm{BKB}=$ batuk kronik berulang $\mathrm{TB}=$ tuberkolosis $\mathrm{BCG}=$ peradangan pada paru $+\mathrm{BCG}$ Pembesaran kelenjar aksila 
Tabel 2. Prevalensi penyakit respiratorik pada anak HIV

\begin{tabular}{lcc}
\hline Diagnosis penyakit respiratorik & n & $\begin{array}{c}\text { Jumlah (\%) } \\
\mathbf{n}=35\end{array}$ \\
\hline Pneumonia & 17 & 44,7 \\
Tuberkulosis & 18 & 47,3 \\
Tersangka PCP* & 5 & 13,1 \\
BKB & 5 & 13,1 \\
BCG itis & 4 & 10,5 \\
\hline
\end{tabular}

$\mathrm{PCP}^{*}=$ pneumocystis carinii pneumonia

Beberapa pasien mempunyai penyakit respiratorik lebih dari satu diagnosis. Pada saat terdiagnosis infeksi HIV pada 17 pasien dengan pneumonia, terdapat 7 pasien dengan riwayat tuberkulosis (TB). Pada 9 pasien $(23,6 \%)$ didiagnosis tuberkulosis bersamaan dengan diagnosis HIV. Dari 5 pasien tersangka pneumocystis carinii pneumonia (PCP), 3 diantaranya didiagnosis PCP pada awal infeksi HIV, sedangkan 2 lainnya dalam perjalanan penyakit HIV, 2 di antaranya juga memiliki riwayat terapi dengan obat anti tuberkolosis(OAT) sebelumnya. Jadi diagnosis TB terdapat pada $18(47,3 \%)$ anak HIV. (Tabel 3)

Penyakit paru yang paling banyak ditemukan adalah TB (47,3\%), diikuti pneumonia (44,7\%) dan tersangka PCP (13,1\%). Tuberkolosis pneumonia dan PCP lebih banyak terdapat pada kelompok umur 14th masing-masing 34,2\%, 34,2\% dan 10,5\%. Sebagian besar pasien mempunyai status gizi buruk (malnutrisi berat) yaitu 57,9\%, dengan kejadian TB $21 \%$ dan pneumonia $18,4 \%$, pneumonia dan TB lebih banyak ditemukan pada status gizi kurang. Sebagian besar anak HIV memiliki status imunitas supresi berat

Tabel 3. Karakteristik penyakit respiratorik pada anak HIV pada awal penyakit

\begin{tabular}{|c|c|c|c|c|c|}
\hline Karakteristik & $(\%)$ & Pneumonia & TB & РCP & $\begin{array}{c}\text { Penyakit respiratorik } \\
\text { lain }\end{array}$ \\
\hline Umur rata-rata (bulan) & 24,1 & & & & \\
\hline \multicolumn{6}{|l|}{ Kelompok umur } \\
\hline - $<12$ bln & $11(28,9)$ & $4(10,5)$ & $2(5,2)$ & $1(2,6)$ & $5(13,1)$ \\
\hline - 1-4 tahun & $24(63,1)$ & $13(34,2)$ & $13(34,2)$ & $4(10,5)$ & $3(7,8)$ \\
\hline - $5-12$ th & $3(7,8)$ & 0 & $3(7,8)$ & 0 & $2(5,2)$ \\
\hline \multicolumn{6}{|l|}{ Jenis kelamin } \\
\hline - laki-laki & $19(50)$ & $12(31,5)$ & $9(50)$ & $2(5,2)$ & $4(10,5)$ \\
\hline - perempuan & $19(50)$ & $5(13,1)$ & $9(50)$ & $3(7,8)$ & $6(15,7)$ \\
\hline \multicolumn{6}{|l|}{ Status gizi } \\
\hline - Buruk & $22(57,9)$ & $7(18,4)$ & $8(21)$ & $3(7,8)$ & $4(10,5)$ \\
\hline - Kurang & $16(42,1)$ & $10(26,3)$ & $10(26,3)$ & $2(5,2)$ & $6(15,7)$ \\
\hline - Baik & 0 & 0 & 0 & 0 & 0 \\
\hline \multicolumn{6}{|l|}{ Kategori HIV } \\
\hline - $\mathrm{A}$ & $3(7,8)$ & $1(2,6)$ & 0 & 0 & $2(5,2)$ \\
\hline - $\mathrm{B}$ & $22(57,9)$ & $11(28,9)$ & $12(31,5)$ & $2(5,2)$ & $5(13,1)$ \\
\hline - $\mathrm{C}$ & $13(34,2)$ & $5(13,1)$ & $6(15,7)$ & $3(7,8)$ & $3(7,8)$ \\
\hline - $\mathrm{N}$ & 0 & 0 & 0 & 0 & 0 \\
\hline \multicolumn{6}{|l|}{ Status imunitas } \\
\hline - Tidak supresi & $6(15,7)$ & $1 \quad(2,6)$ & $3(7,8)$ & 0 & $2(5,2)$ \\
\hline - Supresi sedang & $5(13,1)$ & $2(5,2)$ & $3(7,8)$ & 0 & $1(2,6)$ \\
\hline - Supresi berat & $17(44,7)$ & $9(23,6)$ & $8(21)$ & $2(5,2)$ & $7(18,4)$ \\
\hline - Tidak diperiksa & $10(26,3)$ & $5(13,1)$ & $2(5,2)$ & $3(7,8)$ & 0 \\
\hline \multicolumn{6}{|l|}{ Outcome penyakit paru } \\
\hline - Perbaikan & $25(78,9)$ & $11(28,9)$ & $16(47,3)$ & 0 & $10(26,3)$ \\
\hline - Rekuren & $2(5,2)$ & $1(2,6)$ & 0 & $1(2,6)$ & 0 \\
\hline - Meninggal & $7(18,4)$ & $3(7,8)$ & 0 & $4(10,5)$ & 0 \\
\hline - NA & $5(13,1)$ & $3(7,8)$ & $2(5,2)$ & 0 & 0 \\
\hline
\end{tabular}


(44,7\%) dan supresi sedang 13,1\%. Dihubungkan dengan penyakitnya, maka pneumonia dan TB banyak pada anak HIV dengan status imunitas supresi berat 23,6\% dan 21\%). Anak dengan PCP 5,2\% dengan status imunitas supresi sedang, sedangkan 3 lainnya tidak diperiksa.

Pada Tabel 4 tertera penyakit penyerta yang bersamaan dengan kelainan paru. Oral thrush merupakan kelainan yang terbanyak (8/38), diikuti oleh diare (8/38) dan gagal tumbuh (7/38). Empat dari 5 pasien PCP bersamaan dengan diare.

Demam lama lebih banyak ditemukan pada anak HIV-TB, demikian juga gejala batuk lama. Akan tetapi data tidak dijumpai dari semua pasien. (Tabel 6)

Pada penelitian ini, didapatkan bahwa $3 / 38$ $(7,8 \%)$ anak HIV dengan penyakit paru meninggal karena pneumonia berat, dengan $2 / 3$ di antaranya pada kelompok umur $1-<5$ tahun. Penyebab kematian lainnya adalah tersangka PCP 2/38 pasien $(5,2 \%)$, dan tersangka sepsis pada 2 pasien $(5,2 \%)$.

\section{Diskusi}

Perjalanan penyakit anak yang terinfeksi HIV memiliki beberapa perbedaan dengan orang dewasa. Pertama progresivitas penyakit lebih cepat pada anak ; kedua, anak mempunyai jumlah virus yang lebih banyak dibanding dewasa; dan ketiga, infeksi oportunistik sering muncul sebagai penyakit primer dengan perjalanan penyakit yang lebih agresif karena berkurangnya status imunitas tubuh. ${ }^{7}$

Demam sering ditemukan pada individu dengan imunokompromais. Penyebab demam pada umumnya biasanya infeksi yang sulit didiagnosis. Tidak ada pola demam spesifik yang patognomonik pada infeksi HIV, pada beberapa kasus disebabkan oleh infeksi PCP. ${ }^{8}$ Demikian juga dengan pemeriksaan laboratorium dan foto torak. ${ }^{9}$ Dari data klinis anak HIV dengan penyakit respiratorik pada penelitian ini, ditemukan bahwa demam lama dan batuk lama lebih sering ditemukan pada TB dibanding pneumonia, sedangkan leukosit $>10.000 / \mathrm{mm} 3$ hanya ditemukan pada pneumonia.

Tabel 4. AIDS related illness (ARI) pada anak HIV dengan penyakit respiratorik

\begin{tabular}{lccccccc}
\hline $\begin{array}{l}\text { Penyakit } \\
\text { respiratorik }\end{array}$ & Diare & $\begin{array}{c}\text { Oral } \\
\text { thrush }\end{array}$ & $\begin{array}{c}\text { Gagal } \\
\text { tumbuh }\end{array}$ & $\begin{array}{c}\text { Otitis } \\
\text { media }\end{array}$ & Dermatitis & Anemia & $\begin{array}{c}\text { Kelainan } \\
\text { jantung }\end{array}$ \\
\hline Pneumonia & 8 & 15 & 7 & 3 & 3 & 1 & 5 \\
TB & 13 & 18 & 8 & 4 & 6 & 0 & 3 \\
PCP & 4 & 1 & 3 & 1 & 0 & 0 & 2 \\
Penyakit & 7 & 19 & 4 & 4 & 2 & 0 & 2 \\
respiratorik lain & & & & & & &
\end{tabular}

Tabel 5. Data klinis penyakit respiratorik pada anak HIV

\begin{tabular}{lccccc}
\hline Klinis/laboratorium & n & Pneumonia & TB & PCP & Penyakit respiratorik lain \\
\hline Demam lama & 12 & 7 & 10 & 3 & 5 \\
Batuk lama & 13 & 5 & 6 & 1 & 5 \\
Uji tuberkulin $>5 \mathrm{~mm}$ & 11 & 0 & 1 & 1 & 0 \\
Parut BCG & 12 & 4 & 4 & 1 & 0 \\
Leukosit $<5000 / \mu 1$ & 13 & 0 & 1 & 0 & 1 \\
Leukosit $>10.000 / \mu \mathrm{l}$ & 13 & 1 & 1 & 0 & 0 \\
\hline
\end{tabular}

Tabel 6. Penyebab kematian pada anak HIV dengan infeksi respiratorik

\begin{tabular}{|c|c|c|c|c|c|}
\hline \multirow{2}{*}{$\begin{array}{c}\text { Dugaan penyebab } \\
\text { kematian }\end{array}$} & \multicolumn{3}{|c|}{ Umur (tahun) } & \multirow{2}{*}{$\begin{array}{c}\text { Jumlah HIV-paru } \\
\text { meninggal }(\%) \\
(\mathrm{n}=13))\end{array}$} & \multirow{2}{*}{$\begin{array}{c}\text { Kematian HIV } \\
\text { total }(\%) \\
(\mathrm{n}=38)\end{array}$} \\
\hline & $\begin{array}{c}<1 \\
(n=11)\end{array}$ & $\begin{array}{c}1-4 \\
(n=24)\end{array}$ & $\begin{array}{c}5-12 \\
(n=3)\end{array}$ & & \\
\hline Pneum & 1 & 2 & 0 & $3 / 7$ & $3 / 13$ \\
\hline Tersangka PCP & 1 & 1 & 0 & $2 / 7$ & $2 / 13$ \\
\hline Tersangka Sepsis & 0 & 2 & 0 & $2 / 7$ & $2 / 13$ \\
\hline
\end{tabular}


Namun data ini tidak dapat dijadikan petunjuk oleh karena tidak berasal dari semua pasien.

Di Eropa, lebih dari 80\% anak dengan HIV menderita penyakit paru selama perjalanan penyakitnya. Di Amerika Serikat, pneumonia bakterial lebih sering dijumpai daripada infeksi oportunistik lain pada anak HIV. Kelainan yang paling sering dihubungkan dengan HIV (AIDS related illness $=A R I$ ) adalah Pneumocystis carinii pneumonia (PCP) dan lymphoid interstitial pneumonia (LIP), walaupun saat ini telah berkurang akibat pemberian profilaksis kotrimoksazol. Pada penelitian di Bulawayo terhadap anak HIV yang dilakukan nekropsi, ditemukan PCP 16\%, Cytomegalovirus pneumonia 7\%, LIP 9\% dan tuberkulosis $5 \% .^{5}$

\section{Tuberkulosis}

Infeksi tuberkulosis diketahui dapat mempercepat progresivitas infeksi HIV oleh karena akan meningkatkan replikasi virus HIV. ${ }^{10}$ Pada penelitian ini, didapatkan prevalensi tuberkulosis 47,3\%, dengan proporsi terbesar pada anak dengan kelompok umur 1-4 tahun, dengan status malnutrisi berat 26,3\%, dan status imunitas supresi berat $21 \%$. Keadaan ini hampir sama dengan di Afrika Selatan, tuberkulosis menempati urutan tertinggi pada prevalensi kesakitan anak HIV yaitu 42\%. ${ }^{11}$ Di Rwanda, TB didiagnosis pada 4 dari 16 anak yang diikuti selama 5 tahun. ${ }^{2}$ Tetapi TB tidak sering menjadi sebab kematian, sama seperti pada penelitian ini, tidak ada TB sebagai penyebab kematian.

Masalah utama pada diagnosis TB anak HIV pada penelitian ini adalah diagnosis masih berdasarkan klinis, laboratorium dan foto torak. Tidak semua pasien dapat dilakukan uji tuberkulin dan pemeriksaan BTA dari bilasan lambung oleh karena keterbatasan biaya. Pada kenyataannya, uji tuberkulin pada anak HIV sulit untuk diinterpretasi, oleh karena kemungkinan anergi sangat besar akibat gangguan imunitas seluler. Uji tuberkulin dapat diulang dan kemungkinan anergi tidak menetap pada uji tuberkulin berikutnya, ${ }^{12}$ sehingga masih bermanfaat untuk diagnostik. ${ }^{2} \mathrm{Di}$ Barcelona, 6\% dari anak HIV dengan infeksi TB dapat ditelusuri berdasarkan skrining uji tuberkulin. ${ }^{13}$ Keadaan ini hampir sama dengan yang ditemukan di Afrika Selatan, diagnosis TB pada anak HIV hanya berdasarkan klinis, laboratorium dan foto torak. ${ }^{2} \mathrm{Uji}$ tuberkulin dan riwayat kontak dengan pasien TB dapat membantu. Laboratorium BTA sering negatif dan biakan hanya dilakukan pada sebagian anak HIV, sedangkan foto torak tidak menunjukkan perbedaan antara anak HIV-TB dengan anak HIV-non TB, jadi memang sulit untuk dijadikan petunjuk diagnostik. ${ }^{2}$ Keadaan ini dipersulit lagi oleh gejala HIV-TB yang koinsiden seperti batuk kronik berulang, penurunan berat badan, gagal tumbuh, yang mungkin juga disebabkan oleh PCP.?

\section{Pneumonia bakterial}

Di Amerika Serikat, insiden pneumonia bakteri diperkirakan 11 per 100 orang anak HIV. Pneumonia rekuren dan bakterimia merupakan indikator penyakit AIDS, dengan umur rata-rata 10 bulan. Di Afrika Selatan, dari hasil pemeriksaan post mortem ditemukan klinis pneumonia yang berat dan fatal dihubungkan dengan bakteri S. pneumoniae atau $H$. Influenza. Penelitian di Johannesburg menemukan bahwa bakteremia lebih banyak terdapat pada anak HIV dengan pneumonia yang berat, yang dihubungkan $S$. pneumoniae, $H$. influenza dan E. coli. ${ }^{2}$ Penelitian pada anak HIV di Thailand, didapatkan kematian terbanyak (50\%) disebabkan oleh pneumonia. ${ }^{14}$

Pada penelitian ini, kejadian pneumonia pada anak HIV 44,7\%. Pneumonia merupakan penyebab kematian terbanyak yaitu 3/7 (42,8\%), terutama pada anak berusia $1-4$ tahun $(28,1 \%)$. Kemungkinan penyebab definitif bakteri pada pasien pneumoni tersebut belum dapat ditentukan oleh karena tidak ada data bakteriologis.

Gejala klinis dan hasil terapi dari pneumonia sangat dipengaruhi oleh status nutrisi anak HIV. Anak HIV sering dengan keadaan malnutrisi berat, terutama marasmus. ${ }^{2}$ Pada penelitian ini 7/38 (18,4 \%) anak HIV dengan pneumonia mengalami malnutrisi berat, dan status imunitas supresi berat 9/38 (23,6\%).

Pemeriksaan otopsi pada anak HIV yang mengalami malnutrisi, diisolasi bakteri klebsiella, pseudomonas dan koliform. ${ }^{2}$ Hasil nekropsi juga menunjukkan keadaan malnutrisi pada 50\% anak HIV dan berhubungan bermakna dengan infeksi bakteri di paru. ${ }^{5}$ Pada penelitian di Amerika Serikat ${ }^{15}$ terhadap bayi HIV yang ditularkan oleh ibunya, terdapat gagal tumbuh yang berhubungan bermakna dengan riwayat pneumonia. Keadaan ini menunjukkan bahwa malnutrisi memegang peranan penting dalam perjalanan penyakit pneumonia pada anak HIV. 
Pada satu pasien dari penelitian ini mengalami pneumonia berat, dengan pemberian terapi antibiotik tidak memberi respons, dan secara klinis terdapat perburukan. Pada foto serial, didapatkan infiltrat yang makin meluas, dan pada foto torak terakhir sebelum meninggal didapatkan gambaran bule pada paru kiri. Pemeriksaan bakteriologis tidak dapat dilakukan, sehingga penyebab tidak dapat diketahui. Berdasarkan foto torak terakhir, bakteri penyebab yang mungkin adalah Staphylococcus aureus. Akan tetapi gambaran bulae tersebut juga dapat ditemukan pada PCP, sehingga kemungkinan diagnosis PCP masih bisa dipertimbangkan.

\section{Pneumocystis Carinii Pneumonia}

Kejadian PCP merupakan infeksi oportunistik yang paling sering pada anak HIV di Amerika Serikat dan Eropa. Perkiraan risiko PCP pada tahun pertama kehidupan anak yang terinfeksi HIV perinatal antara 7\%-20\%. Munculan klinis biasanya mulai didapatkan pada masa bayi, sering sebagai keluhan pertama, dan hasil terapinya buruk walaupun terdapat beberapa pilihan terapi. Kejadian PCP dapat dikurangi dengan pemberian profilaksis kotrimoksazol. ${ }^{2}$

Penelitian ini mendapatkan, pada 5 anak HIV dengan tersangka PCP, diagnosis presumtif ditegakkan berdasarkan respons yang buruk terapi antibiotik dan gambaran radiologis yang menunjang PCP. Sebagian besar anak HIV dengan PCP pada kelompok umur 14 tahun $10,5 \%$ dengan status malnutrisi berat 5,2\%, dan status imunitas supresi berat 7,8\%. Kejadian PCP juga sebagai penyebab kematian pada 2 kasus $(28,5 \%)$ dari penyebab kematian seluruhnya. Dua dari diagnosis PCP diduga pada masa awal diagnosis HIV dan langsung sebagai penyebab kematiannya, sedangkan 2 lainnya meninggal akibat sepsis.

Pada pasien PCP yang lain, awalnya dia dirawat dengan diagnosis pneumonia rekuren disertai malnutrisi berat, dan telah mendapatkan profilaksis kotrimokasazol selama 2 bulan. Dalam perjalanan penyakitnya, pasien tidak memberikan respons dengan pemberian antibiotik terhadap pneumonia bakterial, dan pada foto torak terakhir didapatkan gambaran infiltrat yang luas di bagian superior paru. Berdasarkan klinis dan foto torak, ditegakkan diagnosis presumtif PCP, dan diterapi dengan klindamisin dan primakuin, dengan pertimbangan kombinasi ini memberikan efek samping yang minimal, terutama terhadap sistem hematopoetik.
Data otopsi anak HIV di Afrika membuktikan bahwa PCP sering ditemukan pada anak usia kurang dari 6 bulan, pada HIV dewasa, PCP jarang ditemukan. Penelitian prospektif menunjukkan bahwa insiden PCP pada anak HIV yang tidak mendapat profilaksis kotrimoksazol dan dirawat dengan pneumonia berat antara 15\%-17\%, dengan umur rata-rata 3 bulan. Hal ini menunjukkan bahwa PCP biasanya muncul sebagai infeksi primer. Pada anak HIV yang mendapat profilaksis, insiden PCP lebih rendah yaitu 1,7\%. ${ }^{2}$

Anak HIV sering disertai penyakit penyerta, yang sering disebut AIDS related illness ARI juga dijadikan batasan untuk klasifikasi derajat penyakit HIV berdasarkan CDC 1994. Pada penelitian ini, sebagian besar anak HIV yang menderita penyakit paru, juga disertai penyakit lainnya. Berdasarkan kategori CDC, maka sebagian besar termasuk dalam kategori $\mathrm{B}$ (57,9\%), diikuti oleh C $(34,2 \%)$ dan A $(7,8 \%)$.

Pencegahan terhadap penyakit respiratorik pada anak HIV penting dilakukan. Beberapa pedoman yang dilakukan adalah pemberian profilaksis kotrimoksazol untuk pencegahan PCP, kemoprofilaksis isoniazid untuk $\mathrm{TB}$, vaksinasi pneumokokus dan Hib. ${ }^{16}$ Pemberian BCG tidak dianjurkan, ${ }^{3}$ walaupun satu penelitian menemukan bahwa pada $98 \%$ anak HIV yang mendapat BCG, hanya didapatkan $M$. bovis pada 1 anak, dan $M$ tuberkulosis pada 6 anak. ${ }^{9}$ Direkomendasikan juga pemberian mikronutrien seperti vitamin $A$, dan $\mathrm{Zn}$, yang pada beberapa penelitian terbukti efektif dalam mengurangi kejadian penyakit respiratorik pada anak HIV. ${ }^{16}$

Berdasarkan hasil penelitian ini, dapat disimpulkan bahwa morbiditas dan mortalitas penyakit paru pada anak HIV di Bagian Anak RSCM cukup tinggi. Oleh karena itu amat penting untuk dilakukan deteksi dini terhadap setiap anak HIV untuk kemungkinan terinfeksi penyakit paru, dan dilakukan pendataan medis yang lebih lengkap, mulai dari awal penyakit, perjalanan penyakit dan outcomenya. Datadata ini amat bermanfaat untuk pemantauan dan merupakan sumber untuk penelitian yang lebih lanjut.

\section{Daftar Pustaka}

1. Akib AAP. Infeksi HIV pada Bayi dan Anak. Sari Pediatri, 2004 (Suplement);1-14.

2. World Health Organization. Strategic framework to 
decrease the burden of TB/HIV. TB/HIV Working Group. 2002.

3. Working Group on Antiretroviral Therapy and Medical Management of Infants, Children and Adolescent with HIV Infection. Antiretroviral therapy and medical management of pediatric HIV infection. Pediatrics 1998;102:1005-63.

4. Graham SM, Coulter JBS, Gilks CF. Pulmonary disese in HIV-infected African children. Int J Tuberc Lung Dis 2001;5:12-23.

5. Ikeogu MO, Wolf B, Mathe S. Pulmonary manifestations in HIV seropositivity and malnutrition in Zimbabwe. Arch Dis Child 1997;76:124-8.

6. Langston C, Cooper ER, Golfarb J. Human immunodeficiency virus-related mortality in infants and children: data from the pediatrics pulmonary and cardiovascular complication of vertically transmitted (P2C2) study. Pediatrics 2001;107:328-38.

7. Saloojee H, Violari A. HIV infection in children. BMJ 2001;323:670-74.

8. Pizzo PA. Fever in immunocompromised patients. New Engl J of Med 1999; 341:893-900.

9. Zumla A, Malon P, Henderson J, Grange JM. Impact of HIV infection on tuberculosis. Postgrad Med J 2000;76:259-68.

10. Yunihastuti E, Djauzi S, Djoerban Z. Infeksi oportunistik pada AIDS. Pokdisus AIDS FKUI-PDPAI 2005.

11. Rennert WP, Kilner D, Hale M, Stevens G, Stevens W, Crewe-Brown H. Tuberculosis inchildren dying with HIV-related lung disease:clinical-pathological correlations. Int J Tuberc Lung Dis 2002:806-13.

12. Havlir DV, barnes PF. Tuberculosis in patients with human immunodeficiency virus infection. New Engl J of Med 2003;340:5:367-73.

13. Villabi JR, Galdos-Tanguis H, Cayla JA, Casanas P. Tuberculosis infection and disease among schoolchildren: the influence of the HIV epidemic and of other factors. J Epidemol Community Health 1999;53:112-7.

14. Chearskul S, Chotpitayasunondh, Simonds RJ. Survival, disease manifestations, and early predictors of disease progression among children with perinatal Human Immunodeficiency Virus Infection in Thailand. Pediatrics 2002;110:25-30.

15. Miller TL, Easley KA, Zhang W. Maternal and infant factors associated with failure ti thrive in children with vertically transmitted human immunodeficiency Virus1 infection: the prospective, P2C2 Human Immunodeficiency Virus Multicenter Study. Pediatrics 2002; 108:1287-96.

16. Zar HJ. Prevention of HIV-associated respiratory illness in children in developing countries: potential benefits. Int J Tuberc Lung Dis 2003;7:820-7. 